\title{
Brand Identity and Online Self-Customisation Usefulness Perception
}

\begin{abstract}
:
Online self-customisation (OSC) enables customers to tailor their preferences to certain product features via a brand-hosted online platform. Recent literature has given increasing attention to how consumers value OSC. However, extant research is characterised by a scarcity of understanding the effects of brand identity and individual differences on consumer responses to OSC. The purpose of this paper is to examine the mediating role of trust and the moderating role of need for uniqueness on the effects of brand identity prestige and brand identity similarity on consumer perceived usefulness of OSC. A field survey, through mall intercept, was conducted to test this conceptual framework. Our findings advance this field by finding that, not only the brand identity and consumer need for uniqueness, but also the interaction between them may affect consumers' evaluation of OSC.
\end{abstract}

Keywords: Brand identity; online self-customisation; trust; need for uniqueness; perceived usefulness; structural equation modelling 


\section{Brand Identity and Online Self-Customisation Usefulness Perception}

\section{Introduction}

One of the most important recent developments of e-tailing is offering online selfcustomisation (OSC) (or named online mass-customisation), which enables customers to design their own products by tailoring some online good features to fit their personal preferences and expectations (e.g., NikeID) (e.g., Chung, Rust, \& Wedel, 2009; Coelho \& Henseler, 2012; Kaplan \& Haenlein, 2006; Wilcox \& Song, 2011). Concurrent with the expediential interest in explicating service science, research into OSC is garnering much recent attention (e.g., Franke, Keinz, \& Schreier, 2008; Moreau, 2011). This growing body of research reflects the widespread diffusion of pertinent technology among established companies and newly specifically-designed OSC companies (Kaplan, Schoder, \& Haenlein, 2007). Indeed, the Internet offers an excellent platform for OSC, due to its advantage in facilitating customer co-creation during the self-customisation process (Franke et al., 2008) by simplifying the process of self-customisation (Liechty, Ramaswamy, \& Cohen, 2001; Slywotzky, 2000), while enhancing control (Franke, Schreier, \& Kaiser, 2010; Moreau \& Herd 2010).

Online self-customisation refers to a promising service for companies to provide a webbased user toolkit that allows the individual customer to design a product that suits their individual preferences (Franke \& Schreier, 2008). Many companies in different industries have now offered their customers the opportunity to design their own products through OSC service. Examples include; computers (e.g. Dell), apparel (e.g. Levis), mobile phones (e.g. Samsung), sports shoes (e.g. Nike), organic food (e.g. General Mills), cars (e.g. Mini), kitchens (e.g. IKEA), toys (e.g. Lego), and even academic publishers (e.g. McGraw-Hill). Through OSC service, on one side, customers can design their own product to be exactly what they want increasing satisfaction and customer loyalty, whilst on the other side, 
companies may increase their ability to tailor customer needs and be able to charge a premium price for quality (Valenzuela, Dhar, \& Zettelmeyer, 2009). Valenzuela and colleagues (2009) also argue that OSC can be viewed as an important way to enhance customer relationships and reduce competitive threats. Therefore, many companies have now adopted OSC or are considering shifting product design task to customers by using OSC (Franke, et al., 2010; Randall, Terwiesch, \& Ulrich, 2007; Simonson, 2005).

Despite the wide application of OSC by different companies driven by corporate beliefs of the potential value of OSC, it is important to understand the extent to which consumers value OSC (Kaplan et al., 2007). This is because although the technology might have been mature enough to deliver the tantalising benefits of OSC to the companies and potentially enhance the customer perceived values, some of these promises seem to fall short of actual delivery due to low adoption rates (Salvador, de Holan, \& Piller, 2009; Zipkin, 2001). For example, the failures like Levi Strauss (with its "Original Spin”, jeans) have to discontinue their customisation service because it requires extensive customer participation (Franke, Keinz, \& Steger, 2009). Salvador et al. (2009) also argued that the limits of OSC include how to help customers identify or build solutions to their own needs and a strong direct-tocustomer logistics system. Moreover, even though consumers may notice some benefits of using OSC such as fun, convenience, reliability, and so on; companies need to make sure that a platform is set up for consumers to choose their favourite features but not force them to use it. Indeed, unintended negative consequences will arise if customers are forced (rather than choose) to use technology-based self-service. The study of Reinders and colleagues (Reinders, Dabholkar, \& Frambach, 2008) has noted that, when a company obliges their consumers to use technology-based self-service, it is likely to discourage consumers.

In this regard, an improved understanding of the consumer psychological factors in consumer perceived usefulness of OSC could offer important new insights. Accordingly, we 
focus on consumer perceived usefulness, because it is a key consumer evaluation of OSC (Kaplan et al., 2007). Although previous research has noted that perceived ease of use can also be important in determining consumer adoption of OSC (Davis et al, 1989), the relationship between perceived ease of use and perceived usefulness has been widely studied (e.g. Davis, 1989; Davis et al., 1989; Segars \& Grover, 1993; Lu \& Gustafson, 1994). Moreover, extant literature has shown that perceived usefulness is a stronger and more immediate factor than perceived ease of use in predicting intention to adopt a new technology/service (e.g., de Jong, de Ruyter, \& Lemmink, 2003; Davis, 1989; Pavlou, 2003; Venkatesh \& Bala, 2008). Previous research has widely supported the role of perceived usefulness in intentions to adopt, continuing acceptance of new technology, and product innovation (Davies, 1989; Pavlou, 2003), including OSC (Kaplan et al., 2007). Therefore, we used consumers' perceived usefulness as the dependent variable of our study.

Prior research on consumer responses to OSC has examined a wide range of factors, such as the functional utility of OSC to customers (e.g., product attributes/uniqueness, complexity and price) (Dellaert \& Stremersch, 2005; Franke et al., 2008); personal factors, such as self-efficacy (van Beuningen, de Ruyter, Wetzels, \& Streukens, 2009), base category consumption and need satisfaction (Kaplan et al., 2007); system factors, such as online complementary services and toolkits (Dellaert \& Dabholkar, 2009; Franke et al., 2008; Randall, et al., 2007); prior experience (Wilcox \& Song, 2011); and consumer assumed responsibility (Moreau, 2011). Also recent interests of OSC include how consumers evaluate their self-designed products (Franke et al., 2009; Franke \& Schreier, 2010; Moreau, Bonney, \& Herd, 2011) and their decision satisfaction (Syam, Krishnamurthy, \& Hess, 2008; Valenzuela, et al., 2009). However, regarding consumer responses to OSC offered by a certain brand, research on the factors related to the brand itself is scarce. Indeed, although prior research supports that consumer individual difference in need for uniqueness may 
explain consumer acceptance of OSC (Franke \& Schreier, 2008), it is not known how and why a consumer need for uniqueness takes effect. More importantly, little is known on how brand identity and consumer's need for uniqueness may interact to influence how much consumers value OSC.

Brand identity refers to the distinctive and relatively enduring characteristics of a brand. A brand tends to have a strong and attractive identity when its identity is perceived as more distinctive and prestigious (Bhattacharya \& Sen, 2003). Although early literature defines brand identity as an internal construct that represents what organisation managers want the brand to be (Aaker, 1996, de Chernatony, 1999), recent research advances the notion of brand identity by conceptualizing it as dynamic and emanating from multiple actors including companies and customers (da Silveira, Lages, \& Simoes, 2013). The study of Brown and colleagues notes that brand identity is reanimated jointly by stakeholders and a milieu where marketing management and consumer commitment coexist (Brown, Kozinets, \& Sherry, 2003). The dynamic feature of brand identity indicates the salience of the perceptions that company's important stakeholders (e.g. consumers) have toward the brand (Kirmani, Sood, \& Bridges, 1999), which illustrates the prestige of brand identity (Bhattacharya \& Sen, 2003). The dynamic feature of brand identity also reflects its self-expressive benefits - the expression of consumers' self-identity (Aaker, 1996; da Silveira et al., 2013). Consumers are more likely to find a brand that consumers' perceived brand identity is congruent with their own personal or social identity (i.e. brand identity similarity).

Accordingly, this study examines the effects of both brand identity factors (i.e. brand identity prestige and brand identity similarity) (Bhattacharya \& Sen, 2003) and consumer individual differences (specifically consumer need for uniqueness) (Tian, Bearden, \& Hunter, 2001) on consumer perceived usefulness of OSC. Our study intends to investigate the antecedent roles of brand identity prestige and similarity on consumer perceived usefulness of 
OSC; especially we examine the mediating effect of trust and the moderating effect of consumer need for uniqueness on this relationship. Examining the effects of brand identity similarity and prestige enables the inspection of some identity-based motivations (e.g., selfenhancement and self-esteem) (Dunning, 2007; Oyserman, 2007, 2009). Identity-based motivations focus on identity-congruent cognitive process and identity-congruent action in consumer decision making (Oyserman, 2009). Salient identities serve as motivations to integrate information and experiences into the self-concept and protect people's social well being (Leary, 2007; Shavitt, Torelli, \& Wong, 2009). For consumers whose certain social identity is salient, it may activate relevant meanings associated with their in-group identity, which leads to behaviours that increase their perceived similarity to the in-group and enhance positive social identity (Shavitt et al., 2009). Brand identity similarity (between the brand identity and consumer self-image) points to the motivation of self-expression and selfconsistency (Bhattacharya \& Sen, 2003) in adopting OSC services. Whilst previous literature suggests that consumer need for uniqueness, referred to the consumer trait of pursuing differences and enhancing self and social images becomes more relevant as a factor in the context of OSC (Franke \& Schreier, 2008).

These are important under-researched factors for a number of reasons. First, not all brands are equally appealing to customers to design their own products. Brands with stronger prestige may be more suitable for OSC because it may enhance consumer trust and hence result in the perceived usefulness of the online tool. Similar effects may occur for consumers who perceive a strong congruity between their self-identity and that of the brands. Second, prior research indicates that consumer individual differences affect the acceptance of selfcustomisation (Fiore, Lee, \& Kunz, 2004). It has been suggested that self-customisation may be more appealing for consumers with a stronger need for uniqueness (Franke \& Schreier, 2008). However, does this effect occur universally for different consumers regardless of their 
perceived brand identity similarity to their own self-identity? Answering these questions may offer significant suggestions for brands to take a more focused approach in the marketing and designing of their OSC programs.

This study is designed to contribute to the literature by highlighting the significant interactive roles of brand identity, consumers' trust in OSC, and their need for uniqueness in the evaluation of OSC. It demonstrates the positive effects of brand identity on consumer responses to OSC, thus adding valuable evidence to the widely claimed (but rarely evidenced) benefits of brand. It also supports the notion that online marketing tools and general interactive customer-brand interfaces (e.g. OSC) do not necessarily equally appeal to all consumers, but have stronger appeal for consumers with higher need for uniqueness. In addition, the latter are less likely to rely on brand identity similarity in evaluating the usefulness of OSC, which suggests competing motivations of uniqueness and similarity in driving consumer acceptance of OSC.

\section{Conceptual Framework and Hypotheses}

Overall, we propose a model that integrates the effects of brand identity, consumer's trust in OSC, and consumer need for uniqueness on consumer perceived usefulness of OSC. We expect that consumer's trust mediates the effects of brand identity prestige and brand identity similarity on consumer perceived usefulness of OSC. Moreover, consumers' need for uniqueness has a positive direct effect on perceived usefulness of OSC service directly. Finally, consumers' need for uniqueness also moderates the direct effect of brand identity similarity (on top of the indirect effect via trust) on perceived usefulness of OSC. Figure 1 illustrates this conceptual model.

\section{Insert Figure 1 about here.}


Brand identity refers to what the brand stands for among the consumers. Table 1 summarises the prevailing definitions of brand identity. As we argued before, brand identity is the distinctive and relatively enduring characteristics of a focal brand. Although, in general, brand identity can consist of a number of brand attributes such as brand names, logos, slogans, and values, it is the perceptions of the brand identity properties that can affect consumer responses to the brand's marketing activities. In this study, following extant literature (e.g. Bhattacharya \& Sen, 2003), we conceptualise brand identity properties by focusing on two dimensions: brand identity prestige and brand identity similarity. The prestige of brand identity is not just the name, logo, or even the quality for which the brand stands, but more importantly it encompasses the status and perceptions that company stakeholders have toward the brand (Kirmani, Sood, \& Bridges, 1999). Consumers' identification with the prestige of the distinctive brand identity enables them to view themselves in the reflected glory of the company and its brand (Bhattacharya \& Sen, 2003). Brand identity similarity refers to consumers' perceived identity of the company and its brand as congruent with their own personal or social identity. Consumers are more likely to find a brand identity more attractive and desirable when they believe the brand identity matches their own sense of who they are. On the basis of social identity perspective (Ahearne, Bhattacharya, \& Gruen, 2005) and customer-company identification perspective (Bhattacharya \& Sen, 2003), such an operationalisation (i.e. brand identity prestige, brand identity similarity) is consistent with the fundamental dimensions of brand identity as suggested by extant literature. A brand identity is seen as more attractive to consumers when the identity is more prestigious and more similar to the identity of the consumers.

\section{Insert Table 1 about here.}

Brand identity prestige and brand identity similarity are believed to positively relate to consumer perceived usefulness of OSC. Perceived usefulness refers to the degree to which 
consumers believe that a particular technology will facilitate the process (e.g., Davis, 1989; Pavlou, 2003; Venkatesh \& Bala, 2008). A prestigious brand identity could provide a favourable evaluative context for consumers to respond to the brand's marketing activities including OSC service (Keller, 2008). Some consumers may seek self-enhancement in their choice of brands (Kressmann, Sirgy, Herrmann, Huber, Huber, \& Lee, 2006). A prestige brand has an advantage of accommodating such self-enhancement consumer needs, as a prestige brand is bought more importantly for conspicuous consumption (Kirmani et al., 1999). Extant literature also illustrates that the more prestigious consumers perceive the brand identity of a company, the more attractive they will evaluate its brand identity (Bhattacharya \& Sen, 2003), and ultimately enhance their perceived usefulness of the brand's marketing activities (i.e. OSC).

Brand identity similarity is also believed to positively relate to consumer perceived usefulness of OSC. Consumers are motivated to assess brand identity similarity due to their need for self-consistency/self-verification (Morse \& Gergen, 1970; Swann, Griffin, Predmore, \& Gaines, 1987; Swann et al., 1989), and self-expression (Brewer \& Gardner, 1996; Kim \& Drolet, 2003). Self-consistency theory posits that people are motivated to preserve and stabilise their self-views by 'thinking and behaving in ways that perpetuate their conceptions of self' (Swann et al., 1987, p. 881), while self-verification notes that people are invested in preserving their firmly held self-conceptions and do so by soliciting self-verifying feedback (Swann et al., 1989). Self-consistency/self-verification is important because it enables people to predict and control the nature of social reality (e.g., Epstein, 1973). Similarly, consumers could also be motivated to avoid self-dissonance through choice and possession of a branded product that affirms their self-regard (Steele, Spencer, \& Lynch, 1993). Similarly, selfexpression theory argues that 'people make particular choices to paint particular portraits of themselves' (Kim \& Drolet, 2003, p. 373). Accordingly, brands can provide self-expressive 
or symbolic benefits to consumers (Aaker, 1999). Hence, consumers are more prone to respond favourably to a brand (and its marketing activities including OSC) that has an identity that is more similar to their self-concept (Bhattacharya \& Sen, 2003; Sen \& Bhattacharya, 2001). Thus, consumers may be more receptive to OSC offered by brands that have higher identity similarity with them.

\section{The mediation effect of trust}

There are several potential hurdles that prevent consumers from adopting OSC service.

These include: (1) the time investment in specifying product feature preferences, (2) paying a price premium, and (3) increased waiting time to receive the customised product (Bardakci \& Whitelock, 2003). Potentially, such consumer sacrifices discourage consumers from seeing the value of OSC, unless these are out-weighed by consumers' perceived extra benefits from online customisation, such as product benefits, experience benefits, and brand benefits. As noted by Kaplan et al. (2007), both the customised products and the customisation process are important factors in adoption intention. While a number of reasons influence customers' attitudes and decision on online customisation, the extant literature indicates that trust beliefs is the primary reason (Becerra \& Korgaonkar, 2011). Moreover, since the customisation process is enabled by digital technology, consumers' trust in OSC and its system is an important factor in consumer responses to OSC, as it is the case for consumer acceptance of e-commerce and information technology (e.g., Kaplan et al., 2007; van der Heijden, 2004).

Trust is defined as "the expectations held by the consumer that the service provider is dependable and can be relied on to deliver on its services" (Sirdesmukh, Singh, \& Sabol, 2002, p. 17). Consumer trust is an important factor influencing how consumers respond to a brand's marketing activities (Chai \& Dibb, 2014; Jevons \& Gabbott, 2000; Power, Whelan, \& Davies, 2008; Walsh \& Mitchell, 2010). Specifically, trust in an online customisation site 
enhances consumer confidence in the process of online interaction, lowers the risk perception, and enhances global favourable attitude (e.g., Becerra \& Korgaonkar, 2011; Gefen, Benbasat, \& Pavlou, 2008; Pavlou \& Fygenson, 2006). When consumers possess trust in a company or a brand's OSC, their trust can not only overcome the perceived uncertainty or risk of OSC, but also enhance their positive attitudes (i.e. perceived usefulness) toward the OSC and its service. Therefore, consumer trust in OSC can impact positively on their perceived usefulness of OSC.

We believe that consumers' trust in OSC will mediate the relationship between brand identity (i.e. prestige and similarity) and their perceived usefulness of OSC. Trust may be developed from a number of cognitive processes, such as calculation of the costs/rewards of the target brand acting in an untrustworthy manner and perception of the brand's capability to fulfil its promises (Arnott, 2007; Doney \& Cannon, 1997). First, through cognitive calculation, consumers could see a brand with a strong identity (i.e. high prestige and high distinctiveness) as incurring too much cost by acting untrustworthily due to the potential loss of brand reputation, which consequently enhances consumer trust in the brand's OSC. Second, the process of trust building stems from a brand's capability to deliver its promises.

Consumers could see a prestige brand more capable of fulfilling its promises (e.g., promised product quality, promised services) to its customers. Moreover, the prestigious brand can provide valuable information and minimise perceived uncertainties of online customisation (Power et al., 2008). Extant literature also indicates that the reputed and prestigious brands are more likely to enjoy higher level of consumer trust (Sichtmann, 2007). Third, from a social identification perspective, a key process that consumers seek to satisfy their selfenhancement need is to identify with organisations having prestigious brand identity (Bhattacharya \& Sen, 2003). Consequently, as a result of fulfilling their self-enhancement, consumers possess a high level of trust in that organisation and its activities. Based on the 
previous arguments that consumers' perceived brand identity can lead to their trust in OSC, and the trust in OSC may positively relate to consumers' perceived usefulness of OSC, we thus posit the following hypothesis.

Hypothesis 1: Brand identity prestige has an indirect positive relationship, through trust, with perceived usefulness of OSC.

When consumers evaluate the identity of a brand, besides assessing the brand identity itself, consumers also assess the degree of congruence between the identity of the brand and their own self-concept (Bhattacharya \& Sen, 2003; Matzler, Pichler, Füller \& Mooradian, 2011). Brand identity similarity occurs when the brand identity matches consumers' sense of who they are. Trust may also be developed from perceived shared characteristics of the object to be trusted (Levin, Whitener, \& Cross, 2006). First, trust may be built on perceived demographic similarities (Levin et al., 2006), as individuals are motivated to reduce uncertainty through establishing their similarities and differences with a social object (Hogg \& Terry, 2000). Second, as trust is based on expectation on confidence in others' behavior, and as such expectation depends on the strength of the shared goals, perspective, and identity with the target to be trusted (Levin et al., 2006), consumers who perceive the brand with stronger perceived identity similarity are more likely to trust the brand. Indeed, prior research has supported the position that people are more likely to trust those they perceive as having similar outlooks and goals (McPherson, Smith-Lovin, \& Cook, 2001).

Moreover, although direct empirical evidence is not readily available in the extant literature, prior research offers some indirect evidence. Self-congruity theory posits that selfimage congruity can affect brand relationship quality (Kleijnen, de Ruyter, \& Andreassen, 2005; Kressmann et al., 2006), which in turn can enhance consumer trust in the brand and its OSC system. Brand identity similarity has been found to be positively associated with customer satisfaction and brand loyalty (e.g., O'Cass \& Grace, 2008; Sirgy, Grewal, 
Mangleburg, Park, Chon, Claiborne, Johar, \& Berkman, 1997; Yim, Chan, \& Hung, 2007), which in turn suggests a close relationship between identity similarity and trust. Also, it has been found that value congruence is a strong factor in consumer-brand relationship (Zhang \& Bloemer, 2008). Hence, we hypothesise:

Hypothesis 2: Brand identity similarity has an indirect positive relationship, through trust, with perceived usefulness of OSC.

\section{Direct effect of need for uniqueness}

Some consumers have a strong need for uniqueness personality and identity in order to express their individuality to others (Berger \& Heath, 2007). Indeed, seeking to convey a unique individuality is an important Western value (Aroean \& Michaelidou, 2014; Kim \& Markus, 1999). OSC offers consumers a great opportunity to do so. Tian et al. (2001) define consumer need for uniqueness as: "the trait of pursuing differences relative to others through the acquisition, utilisation, and disposition of consumer goods for the purpose of developing and enhancing one's self image and social image" (p. 52). Accordingly, a need for uniqueness becomes more relevant as a factor in the context of OSC than in other IT adoption contexts (e.g., general e-commence adoption). Prior research has only implicitly noted the significant role of need for uniqueness for the adoption of mass-customisation. For example, Franke and Schreier (2008) find that perceived product uniqueness has a positive effect on perceived online customisation utility, and consumer desire for unique product enhances such a positive effect. Fiore, Lee, \& Kunz (2004) find that enhancement of individuality positively predicts consumers' need for the unique product by adopting mass-customisation. Although their study stresses the role of 'uniqueness' in consumer perception of online customisation utility, a formal test of the effect of consumer trait of need for the unique on perceived usefulness of OSC is absent. 
Popularised goods could become less desirable to consumers who have a stronger need for uniqueness. In response to popularised goods, consumers can adopt a number of strategies to symbolise their unique and distinctive identity when choosing products and brands (Tian et al., 2001). First, consumers can purchase novelty goods, handcrafted goods, and personalised items that are not available in mass markets (Thompson \& Haytko, 1997). Second, consumers can creatively alter or use more commonplace products, or assemble them into a unique collection, to extend their uniqueness benefits. Third, consumers can try to use or display a product/service in a way that few other consumers are willing to copy. Among these strategies, the first two are closely related to what OSC offers, as Tian et al. (2001, p. 51) note, 'augmenting these options, mass customisation has arisen from marketers' use of computer-facilitated flexible manufacturing such that consumers may create and customise product designs to their own personal specifications.'

Given that self-customisation allows the alteration of the features and attributes of branded products, it can enhance the self and social meanings of the goods (Addis \& Holbrook, 2001) and encourage the intention to adopt OSC for consumers with a stronger need for uniqueness. Such consumers are more prone to perceive higher usefulness of OSC, as it allows a more efficient fit with consumers' requirements and (hence) offers a great and useful opportunity for these consumers to fulfil their needs for unique products (Fiore et al., 2004; Franke \& Schreier, 2008; Tian et al., 2001). Thus, we posit:

Hypothesis 3: Need for uniqueness has a positive relationship with perceived usefulness of OSC.

\section{Moderating effect of need for uniqueness}

Prior discussion has explained that if consumers find a brand with an identity which is more similar to their self-concept, they are more likely to respond favourably to that brand and its 
OSC service. However, this effect is likely to be conditional on the extent to consumers wanting to meet their need for uniqueness or the need of self-consistence from OSC (Tian et al., 2001). Therefore we are expecting that the effect of brand identity similarity on consumers' perceived usefulness of OSC will depend on the strength of their need for uniqueness.

On one hand, brand identity similarity takes effect due to consumers' motivation to support the brand's marketing activities; on the other hand, consumers' need for uniqueness takes effect due to the motivation of meeting the basic psychological need for being distinctive. As noted earlier, OSC may be seen as more useful for consumers with stronger need for uniqueness, because OSC service enables consumers to tailor certain product features to make the product more unique. In this sense, brand identity similarity and consumers' need for uniqueness represent two identity-related motivations. Whether these motivations are additive or compensatory depends on their compatibility (Baumeister, 1999; Skitka, 2003). Identity-based motivations are more likely to compensate each other when they are incompatible in nature. For example, it has been found that moral identity has a weaker effect on consumer donation when financial incentives are offered (Aquino, Freeman, Reed, Lim, \& Felps, 2009). Based on the concept of hierarchy of multiple identities, social identity tends to be outperformed by personal level basic needs or personal identity to affect attitudes and behaviours (Skitka, 2003). One can accept or reject social identity without losing a basic sense of identity and 'only when one's sense of personal identity is altered does one feel...no longer oneself' (Skitka, 2003, p. 288). When a brand has an identity that is similar to one's self-image, the brand would have limited perceived value to project a more desired distinctive image for consumers with stronger need for uniqueness. Instead, for consumers with a weaker need, in order to fulfil their uniqueness need, the main driving force for accepting the brand's OSC would be consumers' motivation to support the brand's 
marketing activities due to brand identity similarity. Therefore, we expect that brand identity similarity has a stronger (weaker) effect on perceived usefulness of OSC when consumer need for uniqueness is low (high). Thus, we hypothesise:

Hypothesis 4: Need for uniqueness moderates the relationship of brand identity similarity with perceived usefulness; in that brand identity similarity has a stronger positive direct relationship with perceived usefulness, on top of the indirect relationship through trust, when need for uniqueness is low.

\section{Research Design and Methods}

A review of self-customisation research finds that two main methods have been previously used. The first approach involves laboratory experiments that typically use convenient student samples (e.g., Dellaert \& Dabholkar, 2009; Franke et al., 2009; Valenzuela et al., 2009). The second approach uses intercept surveys (e.g., Kaplan et al., 2007) with wider random representative samples. While both methods have strengths and weaknesses, we concur with the comments of Kaplan et al. (2007) who identified the need for research into self-customisation using non-student, more representative samples. Consequently, in order to test the developed hypotheses, a descriptive research design was adopted and an administered intercept survey was deemed the most appropriate data collection method. To ensure that respondents were familiar with the dynamics of OSC processes, during selection for survey participation, survey administrators briefly discussed participants' experience of the nature and forms of OSC.

Concordant with best practice, in order to achieve higher variation of brand identity factors, we selected four internationally-recognised brands: two in the personal computer (PC) sector (i.e. Dell and Apple) and two in the sport shoe sector (i.e. Nike and Adidas). These four brands were chosen for their prominent positions in the respective product category and the availability of OSC programs for competitor brands. Our approach follows earlier studies that have used both PC and sport shoe customisations, in light of their strength 
in enhancing the realism of the study. For example, both the studies of Valenzuela et al (2009) and Wilcox and Song (2011) used laptop computers as the self-customised product and asked their respondents to customize the laptop along different attributes within a price range. The brand of sports shoes were also used in our study since they are widely available in the business world, for example, NIKEiD, MiAdidas, YourReebok, Puma custom shoes, etc.. This mirrors Berger and Heath (2007) who suggested that consumers are more likely to diverge from majorities (pursue uniqueness) in choosing products/brands in product domains that are seen as identity signalling.

To reach consumers with experience of PC or sport shoe online customisation, we targeted consumers at popular shopping locations in London, UK. A sampling plan was developed broadly mirroring the demographic profile of each mall and with a target sample profile aiming to attain 50 responses to each of the four brands. After approaching 562 potential respondents, 199 fully completed questionnaires were obtained (an effective response rate of $35.41 \%$ ), with 50 for each brand except for 49 for Dell. Table 2 illustrates the sample profile.

\section{Insert Table 2 about here}

\section{Measures}

Brand identity prestige and identity similarity are each measured by two items taken from Bhattacharya and Sen (2003). This measurement has also been tested and validated by the existing empirical study. For example, He, Li, and Harris (2012), whose study tested the impact of brand identity on customer value, satisfaction, and ultimately their loyalty, have employed and validated this measure. Moreover, although brand identity has been widely discussed in extant literature, much of the work is conceptual without validated measurements or scales (e.g. Aaker, 1996; de Chernatony, 1999; Burmann, Jost-Benz, \& 
Riley, 2009). Within the limited number of empirical studies that developed their own brand identity measurements (e.g. Coleman, de Chernatony, \& Christodoulides, 2011; Viot, 2011), we found that they are less appropriate for our research. For example, the measurement developed by Coleman and colleagues (2011) focuses on the B2B service brand identity. The measurement of brand identity developed by Viot (2011) has 41 items which is too lengthy and not suitable for our study using mall intercept to collect the data.

Perceived usefulness of OSC was measured via a scale adapted from Kaplan et al. (2007). Trust in the OSC was taken from Pavlou (2003) whose original scales were designed to fit the context of general e-commerce. We slightly adapted them to fit the context of OSC. Consumers' need for uniqueness was measured by the well-established scale developed by Tian et al. (2001) who conceptualise need for uniqueness with three dimensions: creative choice counterconformity that refers to individuals' ability to use products in a way to create a personal style and self-image socially acceptable and approved by others in the social circle, unpopular choice counterconformity that refers to the consumer's use of products that deviate from the social norm, therefore running the risk of social disapproval, yet could still enhance self-image, and avoidance of similarity that refers to products that are widely used are not bought or used as the aim as a unique image is desirable (Thompson \& Haytko, 1997). With the exception of standard demographic measures, five-point Likert-type scoring was adopted. The scales were anchored by 'Strongly Disagree' (1) to 'Strongly Agree' (5). Appendix A shows the individual items in relation to the latent variables.

\section{Data Analysis and Findings}

\section{Confirmatory Factor Analysis}

We applied confirmatory factor analysis (CFA) to assess the psychometric properties of the scales used in the study. Need for uniqueness scale was conceptualized and modelled as a 
second order latent variable (Tian et al., 2001), and other variables were single order latent variables. To gauge the validity of the estimated model, a range of absolute, incremental, and parsimonious fit measures were employed. Absolute fit was evaluated via the Root Mean Square Error of Approximation (RMSEA), which supported acceptance of the model. Incremental fit was evaluated via Bollen's (1989) Incremental Fit Index (IFI) and Bentler's (1990) Comparative Fit Index (CFI), both of which represent comparisons between the estimated model and a null model. The CFI of 0.94 and IFI of 0.94 indicate strong support for the estimated model. Finally, the parsimonious fit measure employed was the Marsh and Hocevar (1985) test of dividing chi-squared by the degrees of freedom $\left(\chi^{2} / \mathrm{df}\right)$ and was calculated generating a ratio of 1.799 (well below the ratio threshold suggested by Byrne, 1989). Thus, given that CFA produced goodness-of-fit of CFI $=.94, \mathrm{IFI}=.94 ; \chi^{2}=316.687$ $(176), \chi^{2} / \mathrm{df}=1.799, \mathrm{RMSEA}=.064$, it was concluded that the measurement model was sufficiently valid.

Appendix A presents the factor loadings of individual items and first-order latent variables for the proposed measurement model. All factor loadings are over the .50 threshold $(p<.001)$. To further test the convergent and discriminant validity of our measures, we calculated the average variance extracted (AVE) and Cronbach alpha of all scales; and compared the square root of the AVE score of any construct with its associated squared correlations (Fornell \& Larcker, 1981). The scores are presented in Table 3, which also presents the descriptive statistics and correlations of all variables. The AVEs and composite reliabilities of all variables are over the .50 and .70 thresholds respectively, which further confirms the convergent validities of the measures. Table 3 also shows the square roots of all AVE scores are higher than all correlations of the focal construct with other variables, which supports the discriminant validity of the measures (Fornell \& Larcker, 1981). 


\section{Hypotheses testing}

To test the main and direct hypotheses, we ran a structural model that specifies the paths based on the proposed framework. The model achieves good fit: $\mathrm{CFI}=.94$, IFI $=.94 ; \chi^{2}=$ $319.985(179), \chi^{2} / \mathrm{df}=1.788, \mathrm{RMSEA}=.063$. To gauge this model, we compared this preferred model with a competing model that adds the direct paths from brand identity prestige and brand identity similarity to perceived usefulness of OSC with the following fit: $\mathrm{CFI}=.94, \mathrm{IFI}=.94 ; \chi^{2}=317.114(177), \chi^{2} / \mathrm{df}=1.792, \mathrm{RMSEA}=.063$, assuming that brand identity prestige affects perceived usefulness directly on top of its path through trust. This competing model produced insignificant path coefficients estimates for both paths while the proposed model is not significantly worse than the competing model $\left(\Delta \chi^{2}=2.872, \Delta \mathrm{df}=2, p\right.$ $=.24)$. Accordingly, the proposed model is a preferred one based on the grounds of parsimony (Rindskopf \& Rose, 1988). Table 4 presents the estimation results of the estimated paths.

\section{Insert Table 4 about here}

Hypotheses 1 and 2 expect indirect effects by brand identity prestige and brand identity similarity on perceived usefulness through consumers' trust in OSC. We calculated the indirect effects, performing bias corrected confidence interval through bootstrapping (MacKinnon, Lockwood, \& Williams, 2004). Both indirect effects are significant. Brand identity prestige has a significant indirect effect on perceived usefulness via trust $(\beta=.19, p$ $<.01$; confidence interval: $\beta=.06$ to $\beta=.34$ ). Thus Hypothesis 1 is supported. Brand identity similarity also has a significant indirect effect on perceived usefulness via trust $(\beta=.03, p$ $=.05$; confidence interval: $\beta=.00$ to $\beta=.08$ ). Consequently, Hypothesis 2 is also supported.

Hypothesis 3 predicts that consumer need for uniqueness positively relates to perceived usefulness. We also tested a competing model that adds the path from need for uniqueness to 
trust, assuming that need for uniqueness has an indirect effect on perceived usefulness through trust. This alternative model does not perform better than the proposed model ( $p$ $=.55$ ) and the direct path from need for uniqueness on trust is not significant. Therefore, the proposed full mediation of need for uniqueness model is preferred and Hypothesis 3 is supported $(\beta=.24, p<.05)$.

Hypothesis 4 states that consumers' need for uniqueness moderates the effect of brand identity similarity on perceived usefulness of OSC. That is, brand identity similarity has a positive direct effect on perceived usefulness when consumer need for uniqueness is low. To test this hypothesis, we adopted the standardised residue centring approach of moderated SEM (Little, Bovaird, \& Widaman, 2006) with the three dimensions of need for uniqueness scale as three indicators to be interacted with the two indicators of brand identity similarity.The model achieved adequate fit: $\mathrm{CFI}=.93, \mathrm{IFI}=.93 ; \chi^{2}=525.477(294), \chi^{2} / \mathrm{df}=$ 1.787 , RMSEA $=.063$. The model results show that the interaction between brand identity similarity and need for uniqueness is significantly negative $(\beta=-.17, p<.05)$, suggesting that when need for uniqueness is lower (one standard deviation below mean), brand identity similarity has a positive effect on perceived usefulness $(\beta=.28 ; p<.01)$, even when trust is controlled for; however, when need for uniqueness is higher (one standard deviation above mean), the effect of brand identity similarity is insignificant $(\beta=-.06, n s)$. Thus, Hypothesis 4 is supported. Figure 2 illustrates the pattern of this interactive effect on perceived usefulness.

\section{Insert Figure 2 about here}

\section{Implications and Conclusions}

\section{Theoretical implications}

This study tested the antecedents (i.e., brand identity prestige and brand identity similarity), mediator (consumer trust in OSC), and moderator (need for uniqueness) on the perceived 
usefulness of OSC. The analyses of the empirical data reach the following main findings. First, both brand identity prestige and brand identity similarity have significant indirect effects on perceived usefulness of OSC through consumer trust in OSC. Second, consumer need for uniqueness has a positive direct effect on perceived usefulness of OSC. Finally, in addition to the indirect effect via trust on perceived usefulness, brand identity similarity has a positive direct effect on perceived usefulness for consumers with weaker need for uniqueness.

This study contributes to the self-customisation literature by highlighting the significant role of brand identity on consumer responses to OSC. It demonstrates the positive effects of brand identity on consumer responses to companies' marketing programmes, thus adding valuable evidence to the widely claimed (but rarely evidenced) benefits of brand identity and identity management (e.g., Bhattachaya \& Sen, 2003). Moreover, our study indicates that OSC might not be equally appealing for all brands. Brands with a prestigious identity or an identity that mirrors the identities of consumers are more likely to receive favourable responses. This is due to the higher consumer trust in the OSC service that is derived from stronger brand identity prestige and similarity. As noted earlier, although prior research has identified a wide range of factors in consumer responses to OSC, none has examined the role of brand identity.

Second, this research tests an alternative explanation of the effect of brand identity prestige and brand identity similarity on perceived usefulness. However, in addition to their indirect effects through trust, we failed to find a significant direct effect. This result suggests that brand identity prestige and similarity does not directly enhance consumer favourable responses to OSC for other reasons, such as self-enhancement or self-congruency derived from the brand itself. Although brand identity prestige and similarity were proposed to positively relate to consumer perceived usefulness of OSC based on the self-enhancement theory and self-consistency theory, our results do not support the direct relationships. 
Actually, this is to some extent not surprising, as the self-enhancement or congruent effect derived from brand identity prestige and similarity could be achieved by choosing the brand itself (Kirmani et al., 1999), without necessarily using the OSC by the brand. As expected, our study found an important mediating mechanism, which is consumer's trust in OSC. In essence, this mechanism indicates an important motivational power by strong brand identity. That is, the brands with strong identity prestige and similarity to consumers are more likely to lead to high consumer's trust on these brands adopting OSC. Ultimately, this results in consumers' high perceived usefulness for OSC service. Our study confirms the central role that trust plays in managing a successful OSC service. Without the increments of trust in OSC, consumer perceived brand identity and similarity is good but not good enough to create high evaluation on OSC service.

Third, this research supports the notion that OSC does not necessarily equally appeal to all consumers, but has a stronger appeal to consumers with higher need for uniqueness. This result supports the notion that OSC offers consumers the means to obtain products in a convenient way that could be potentially personally unique, hence meeting consumers' need for product uniqueness. In addition, intriguingly, the results find that consumer need for uniqueness moderates the impact of brand identity similarity on the perceived usefulness of OSC. This implies that unlike brand identity prestige, brand identity similarity may, in addition to its indirect effect via trust, affect consumer perceived usefulness of OSC for the reason of supporting a brand's marketing activities. However, this motive is present only when the motive of meeting the need for uniqueness is low. When consumers have a general stronger need for product uniqueness, evaluation of the OSC would be mainly driven by this basic psychological need, hence less driven by the social identity-based motivation to support the focal brand's marketing activities. 


\section{Managerial implications}

Although more and more companies have now offered their customers the opportunity to design their own products through OSC service, the adoption rate for this service is still relatively low and slow in progress, as customers need to deal with different product features and estimate various product functions (de Bellis, Hildebrand, Ito, \& Herrrmann, 2015; Park, Han, \& Park, 2013). Our study sheds new insights into how to promote the adoption of OSC service in general. First, our study supports the central role of trust in customers' adoption of OSC service. Extant studies indicated that consumers' perceived risk plays an important negative role in online customization (de Jong et al., 2003; Lee \& Allaway, 2002; Park et al., 2013). Customers' trust in OSC does not only directly lead to their perceived usefulness of OSC, but also mediates the effect of brand identity on perceived usefulness. Therefore, it is more effective to enhance consumer's trust in promoting OSC service. The important role of trust suggests that companies should try to build trusting relationships with their customers by having high security, effective privacy, reliable service, dependable functions, and userfriendly systems with their OSC

Second, a brand with the strong identity prestige and similarity may increase consumers' adoption of OSC service. The significant (indirect) effects of brand identity prestige and brand identity similarity on perceived usefulness suggest that (a) OSC is more readily acceptable by consumers for brands with stronger brand identity and with a larger base of customers who resonate with the identity of the brand; (b) the targeting and promotion of the OSC tool should be more tailored towards those consumers who have stronger and more favourable perceived identity towards the brand. Therefore, it has now become even more important for companies to have some high status positioning and unique differentiation to build brand identity prestige to their target customers. The brand identity prestige and similarity can be developed and achieved through the use of advertising message 
that communicates with the product and service quality of OSC. For example, one prior study indicates that the prestige of the brand can be enhanced by increasing consumer's perception of the service quality (Hwang \& Han, 2014).

Third, while it is important for companies to enhance the OSC systems and configurations, it is also important for them to understand the identity-based motivations of customers to adopt OSC. Little doubt exists that online customisation does not appeal to all customer segments. This study finds that identity-related motivations $d o$ matter for consumer intentions to adopt OSC. The significant direct effect of consumers' needs for uniqueness on perceived usefulness of OSC reveals that companies should target those consumers with stronger need for uniqueness to promote their OSC service. Based on extant studies, consumers with high need for uniqueness are more likely to shop at specialty and upscale department stores, but less at mass-merchandise stores. Tian and McKenzie (2001) have noted that consumers high in need for uniqueness normally shop a greater variety of retail outlet types and tend to be associated with finding unique goods in the antique shops, custom builders-makers etc.. In addition, when communicating to these consumers, the message should be based on contents and appeals that stress the value of OSC for accommodating the need for uniqueness. For example, the OSC service should be designed to enhance customers' perceptions that their self-designed products are unique. As suggested by Franke and Schreier (2008), the OSC service may provide immediate feedback during the designing process to indicate if other customers have already come up with the same designs. This may create more values for customers with high need for uniqueness.

Many companies are setting up OSC platform so that customers can design products by themselves. Our research indicates that, like many other consumer goods using masscustomisation such as T-shirts, cell phone covers, watches (Franke et al.,2010), products of sports shoes and personal computers are also self-expressive and suitable for OSC service. 
Companies making these products should try to build the brand identity by enhancing their brand prestige and similarity to the user's image, cultivate consumers' trust, and deliver the unique value of their OSC service.

\section{Limitations and future research}

This study has a number of limitations that can suggest important avenues for future research. First, our sample size is relatively small. Also, this study chose only four brands. Despite that, all four brands and their associated products are very relevant product categories for OSC; future research can apply other brands or more brands from different industries. Second, the study was conducted by street intercept in London, UK. Although we have discussed the reasons for selecting this method, future studies could be conducted in other cities/countries or using laboratory experiments to compare with the present findings. Third, two dimensions, i.e. identity prestige and identity similarity, were borrowed from Bhattacharya and Sen (2003) for consumers' perceived brand identity. Another dimension of brand identity is identity distinctiveness. We did not include this dimension because there is no strong theoretical argument to support the relationship between identity distinctiveness and trust. For example, being distinctive does not necessarily mean that it can lead to consumers' trust on the focal brand's online-customisation service. Since our main focus is to find how trust can explain how consumers' perceived brand identity influences their perceived usefulness of OSC, we only include brand identity prestige and similarity in our study. Also, the measurement is based on the conceptual work of Bhattacharya and Sen (2003). Although other empirical study (e.g. He et al., 2012) has tested and validated this measurement, it might be a limitation as there are only two items for each dimension. Future research may apply other measurements that have been empirically developed and tested (e.g. Coleman, de Chernatony, \& Christodoulides, 2011). 
Fourth, this study focuses on identity-based motivational factors but largely ignores emotional factors. Recent studies have identified that customer emotional attachment with a brand has significant impact on responses to the brand's marketing activities and programmes (e.g., Carroll \& Ahuvia, 2006; Thomson, Maclnnis, \& Park, 2005). Therefore, future search should incorporate these emotional factors to explain consumer intention to adopt OSC. Corporate social responsibility has been recently applied to explain consumer responses to a company's marketing programmes, such as cause-related marketing and new products/services. Future research may examine how corporate social responsibility can affect consumer responses to OSC. One of the potential explanations is that a brand with stronger CSR image can enhance consumer trust in, hence perceived usefulness of its OSC. Fifth, we only used the perceived usefulness of OSC as the dependent variable in our study. Although perceived usefulness of OSC is an important predictor for consumers' online shopping behaviour (Kaplan et al., 2007), future research may investigate other factors such as perceived ease of use, purchase intention of OSC, and willingness to pay a premium price. Sixth, the experience level of using OSC might play an important role in consumer perceived usefulness of OSC. Particularly, future research may explore the potential moderating effect of consumer experience on the relationship between brand identity and perceived usefulness of OSC. Finally, this research does not expect that consumer need for uniqueness would cause brand identity prestige to have a direct effect on perceived usefulness on top of the indirect effect via trust. However, we cannot rule out the possibility that brand identity prestige can have a direct effect (on top of trust) on perceived usefulness, as people might be willing to take some extra risk to use the online self-customisation service of a prestigious brand. These people could be motivated to seek high status, instead of uniqueness. However, our research does not advance this line of argument. This as a limitation for our research, and 
future research should be conducted to test the conditions under which brand identity prestige can have direct effect on perceived usefulness on top of the direct effect via trust. 


\section{Appendix A: Variables, measures and factor loadings}

\section{Measurement Items (loadings)}

Need for uniqueness (Tian et al., 2001; AVE $=.55$ )

Creative choice $(.83)$

I often combine possessions in such a way that I create a personal image that cannot be duplicated. (.74)

I often try to find a more interesting version of run-of-the-mill products because I enjoy being original. (.80)

I actively seek to develop my personal uniqueness by buying special products or brands. (.73)

Having an eye for products that are interesting and unusual assists me in establishing a distinctive image. (D) ${ }^{\mathrm{a}}$

Unpopular choice (.73)

When it comes to the products I buy and the situations in which I use them, I have broken customs and rules. (.76)

I have often violated the understood rules of my social group regarding what to buy or own. (.71)

I have often gone against the understood rules of my social group regarding when and how certain products are properly used. (.90)

I enjoy challenging the prevailing taste of people I know by buying something they would not seem to accept. (.78)

Similarity avoidance (.66)

When a product I own becomes popular among the general population, I begin to use it less. (.70)

I often try to avoid products or brands that I know are bought by the general population. (.84)

As a rule, I dislike products or brands that are customarily bought by everyone. (.85)

The more commonplace a product or brand is among the general population, the less interested I am in buying it. (.84)

Brand Identity similarity (Bhattacharya \& Sen, 2003; AVE $=.83$ )

I recognise myself in $\mathrm{X}(1.05)$

My sense of who I am matches my sense of X (.74)

Brand identity prestige (Bhattacharya \& Sen, 2003; AVE $=.63$ )

$\mathrm{Y}$ is a first-class, high-quality brand (.81)

$\mathrm{Y}$ has a high reputation $(.77)$

Trust in OSC (Pavlou, 2003; AVE = .69)

The online customisation services of Y seem to be trustworthy. (.77)

The Y brand and company is reliable. (.79)

I can rely on $\mathrm{Y}$ customisation services to deliver their promises to me. (.90)

Perceived usefulness of OSC (Kaplan et al., 2007; AVE = .62)

I would find $\mathrm{X}$ very useful to me. (.75)

Being able to customise $\mathrm{X}$ would enable me to fulfil my purpose of buying the product. (.79)

I would very much enjoy $\mathrm{X}$ that I could customise to my taste and preferences. (.82)

$\mathrm{X}$ represents the product. Y represents the brand.

${ }^{a}$ Removed due to low item-to-total correlation. 


\section{REFERENCES}

Aaker, D. A. (1996). Building strong brands. New York: The Free Press/Simon and Schuster.

Aaker, J. L. (1999). The malleable self: The role of self-expression in persuasion. Journal of Marketing Research, 36(1), 45-57. doi: 10.2139/ssrn.945453

Aaker, D. A., \& Joachimsthaler, E. (2000). Brand leadership. New York: The Free Press.

Addis, M., \& Holbrook, M. B. (2001). On the conceptual link between mass customization and experiential consumption: An explosion of subjectivity. Journal of Consumer Behaviour, 1(1), 50-66. doi: 10.1002/cb.53

Ahearne, M., Bhattacharya, C. B., \& Gruen, T. (2005). Antecedents and consequences of customer- company identification: expanding the role of relationship marketing. Journal of Applied Psychology, 90(3), 574-585. doi: 10.1037/0021-9010.90.3.574

Aquino, K., Freeman, D., Reed II. A., Lim, V. K. G., \& Felps, W. (2009). Testing a socialcognitive model of moral behavior: The interactive influence of situations and moral identity centrality. Journal of Personality and Social Psychology, 97(1), 123-141. doi: $10.1037 / \mathrm{a} 0015406$

Arnott, D. C. (2007). Trust - current thinking and future research. European Journal of Marketing, 41(9/10), 981-987. doi: 10.1108/03090560710773291

Aroean, L., \& Michaelidou, N. (2014). Are innovative consumers emotional and prestigiously sensitive to price?. Journal of Marketing Management, 30(3-4), 245-267, doi: 10.1080/0267257X.2013.811094

Bardakci, A., \& Whitelock, J. (2003). Mass-customisation in marketing: the consumer perspective. Journal of Consumer Marketing, 20(4/5), 463-479. doi:

$10.1108 / 07363760310489689$ 
Baumeister, R. F., (1999). Self-concept, self-esteem, and identity. In V. Derlega, B. Winstead, \& W. Jones (Eds.), Personality: Contemporary theory and research (2nd ed.), Chicago: Nelson-Hall. 339-375.

Becerra, E. P., \& Korgaonkar, P. K. (2011). Effects of trust beliefs on consumers' online intentions. European Journal of Marketing, 45(6), 936-962. doi: $10.1108 / 03090561111119921$

Bentler, P. M. (1990). Comparative fit indexes in structural models. Psychological Bulletin, 107(2), 238-246. doi: 10.1037/0033-2909.107.2.238

Berger, J., \& Heath, C. (2007). Where consumers diverge from others: Identity signaling and product domains. Journal of Consumer Research, 34(2), 121-134. doi: 10.1086/519142

Bhattacharya, C. B., \& Sen, S. (2003). Consumer-company identification: A framework for understanding consumers' relationships with companies. Journal of Marketing, 67(2), 7688. doi: 10.1509/jmkg.67.2.76.18609

Bollen, K. A. (1989). Structural equations with latent variables. Oxford, England: John Wiley \& Sons.

Brewer, M. B., \& Gardner, W. (1996). Who is this "We"? Levels of collective identity and self representations. Journal of Personality and Social Psychology, 71(1), 83-93. doi: $10.1037 / 0022-3514.71 .1 .83$

Brown, S., Kozinets, R.V., \& Sherry, J.F. (2003).Teaching old brands new tricks: retro branding and the revival of brand meaning. Journal of Marketing, 67(3), 19-33. doi: 10.1509/jmkg.67.3.19.18657

Byrne, B. M., Shavelson, R. J., \& Muthén, B. (1989). Testing for the equivalence of factor covariance and mean structures: The issue of partial measurement invariance. Psychological Bulletin, 105(4), 456-466. doi: 10.1037/0033-2909.105.3.456 
Carroll, B. A., \& Ahuvia, A. C. (2006). Some antecedents and outcomes of brand love. Marketing Letters, 17(2), 79-89. doi: 10.1007/s11002-006-4219-2

Chai, J. C. Y., \& Dibb, S. (2014). How consumer acculturation influences interpersonal trust, Journal of Marketing Management, 30(1-2), 60-89, doi: 10.1080/0267257X.2013.803140

Chung, T. S., Rust, R. T., \& Wedel, M. (2009). My mobile music: An adaptive personalization system for digital audio players. Marketing Science, 28(1), 52-68. doi: $10.1287 / \mathrm{mksc} .1080 .0371$

Coelho, P. S., \& Henseler, J. (2012). Creating customer loyalty through service customization. European Journal of Marketing, 46(3/4), 331-356. doi: 10.1287/mksc.1080.0371

Coleman, D. de Chernatony, L., \& Christodoulides, G. (2011). B2B service brand identity: Scale development and validation. Industrial Marketing Management, 40(7), 1063-1071. doi:10.1016/j.indmarman.2011.09.010

da Silveira, C., Lages, C., \& Simoes, C. (2013). Reconceptualizing brand identity in a dynamic environment. Journal of Business Research, 66(1), 28-36. doi:10.1016/j.jbusres.2011.07.020

Davis, F. D., Bagozzi, R. P., \& Warshaw, P. R. (1989). User acceptance of computer technology: A comparison of two theoretical models. Management Science, 35(8), 9821003. doi: $10.1287 / \mathrm{mnsc} .35 .8 .982$

de Bellis, E., Hildebrand, C., Ito, K., \& Herrmann, A. (2015). Cross-national differences in uncertainty avoidance predict the effectiveness of mass customization across East Asia: A large-scale field investigation. Marketing Letters, 26(3), 309-320. doi: 10.1007/s11002015-9356-Z

de Chernatony, L. (2006). From brand vision to evaluation. Oxford: ButterworthHeinemann.de Chernatony, L. (1999). Brand management through narrowing the gap 
between brand identity and brand reputation. Journal of Marketing Management, 15(1-3), 157-179. doi: 10.1362/026725799784870432

de Jong, A., de Ruyter, K., \& Lemmink, J. (2003). The adoption of information technology by self-managing service teams. Journal of Service Research, 6(2), 162-179. doi: $10.1177 / 1094670503257046$

Dellaert, B. G. C., \& Dabholkar, P. A. (2009). Increasing the attractiveness of mass customization: The role of complementary on-line services and range of options. International Journal of Electronic Commerce, 13(3), 43-70. doi: 10.2753/JEC10864415130302

Dellaert, B. G. C., \& Stremersch, S. (2005). Marketing mass-customized products: Striking a balance between utility and complexity. Journal of Marketing Research, 42(2), 219-227. doi: $10.1509 / \mathrm{jmkr} .42 .2 .219 .62293$

Doney, P. M. \& Cannon, J. P. (1997). An examination of the nature of trust in buyer-seller relationships. Journal of Marketing, 61(2), 35-51. doi: 10.2307/1251829

Dunning, D. (2007). Self-image motives and consumer behavior: How sacrosanct self-beliefs sway preferences in the marketplace. Journal of Consumer Psychology, 17(4), 237-249. doi: $10.1016 / \mathrm{S} 1057-7408(07) 70033-5$

Epstein, S. (1973). The self-concept revisited: Or a theory of a theory. American Psychologist, 28(5), 404-416. doi: 10.1037/h0034679

Fiore, A. M., Lee, S-E., \& Kunz, G. (2004). Individual differences, motivations, and willingness to use a mass customization option for fashion products. European Journal of Marketing, 38(7), 835-849. doi: 10.1108/03090560410539276

Fornell, C., \& Larcker, D. F. (1981). Evaluating structural equation models with unobservable variables and measurement error. Journal of Marketing Research, 18(1), 3950. 
Franke, N., \& Schreier, M. (2008). Product uniqueness as a driver of customer utility in mass customization. Marketing Letters, 19(2), 93-107. doi: 10.1007/s11002-007-9029-7

Franke, N., Keinz, P., \& Schreier, M. (2008). Complementing mass customization toolkits with user communities: How peer input improves customer self-design. Journal of Product Innovation Management, 25(6), 546-559. doi: 10.1111/j.1540-5885.2008.00321.x

Franke, N., Keinz, P., \& Steger, C. J. (2009). Testing the value of customization: When do customers really prefer products tailored to their preferences?. Journal of Marketing, 73(5), 103-121. doi: 10.1509/jmkg.73.5.103

Franke, N., \& Schreier, M. (2010). Why customers value self-designed products: The importance of process effort and enjoyment. Journal of Product Innovation Management, 27(7), 1020-1031. doi: 10.1111/j.1540-5885.2010.00768.x

Franke, N., Schreier, M., \& Kaiser, U. (2010). The "I designed it myself" effect in mass customization. Management Science, 56(1), 125-140. doi: 10.1287/mnsc.1090.1077

Gefen, D., Benbasat, I., \& Pavlou, P. A. (2008). A research agenda for trust in online environments. Journal of Management Information Systems, 24(4), 275-286. doi: 10.2753/MIS0742-1222240411

He, H., Li, Y., \& Harris, L., (2012). Social identity perspective on brand loyalty. Journal of Business Research, 65(5), 648-657. doi:10.1016/j.jbusres.2011.03.007

Hogg, M. A., \& Terry, D. I. (2000). Social identity and self-categorization processes in organizational contexts. Academy of Management Review, 25(1), 121-140. doi: 10.5465/AMR.2000.2791606

Hwang, J., \& Han, H. (2014). Examining strategies for maximizing and utilizing brand prestige in the luxury cruise industry. Tourism Management, 40, 244-259. doi: 10.1016/j.tourman.2013.06.007 
Jevons, C., \& Gabbott, M. (2000). Trust, brand equity and brand reality in internet business relationships: An interdisciplinary approach. Journal of Marketing Management, 16(6), 619-634. doi: 10.1362/026725700785045967

Kapferer, J. N. (1992). Strategic Brand Management. London: Kogan Page.

Kaplan, A. M., \& Haenlein, M. (2006). Toward a parsimonious definition of traditional and electronic mass customization. Journal of Product Innovation Management, 23(2), 168182. doi: $10.1111 / \mathrm{j} .1540-5885.2006 .00190 . \mathrm{x}$

Kaplan, A. M., Schoder, D., \& Haenlein, M. (2007). Factors influencing the adoption of mass customization: The impact of base category consumption frequency and need satisfaction. Journal of Product Innovation Management, 24(2), 101-116. doi: 10.1111/j.15405885.2007.00237.x

Keller, K. L. (2008). Strategic brand management: Building, measuring, and managing brand equity (3rd ed.), New Jersey: Prentice Hall.

Kim, H., \& Markus, H. R. (1999). Deviance or uniqueness, harmony or conformity? A cultural analysis. Journal of Personality and Social Psychology, 77(4), 785-800. doi: $10.1037 / 0022-3514.77 .4 .785$

Kim, H. S. \& Drolet, A. (2003). Choice and self-expression: A cultural analysis of varietyseeking. Journal of Personality and Social Psychology, 85(2), 373-382. doi: $10.1037 / 0022-3514.85 .2 .373$

Kirmani, A., Sood, S., \& Bridges, S. (1999). The ownership effect in consumer responses to brand line stretches. Journal of Marketing, 63(1), 88-101.

Kleijnen, M., de Ruyter, K., \& Andreassen, T. W. (2005). Image congruence and the adoption of service innovations. Journal of Service Research, 7(4), 343-359. doi: $10.1177 / 1094670504273978$ 
Kressmann, F., Sirgy, M. J., Herrmann, A., Huber, F., Huber, S., \& Lee, D-J. (2006). Direct and indirect effects of self-image congruence on brand loyalty. Journal of Business Research, 59(9), 955-964. doi: 10.1016/j.jbusres.2006.06.001

Leary, M. R. (2007). Motivational and emotional aspects of the self. Annual Review of Psychology, 58(1), 317-344. doi: 10.1146/annurev.psych.58.110405.085658

Lee, J., \& Allaway, A. (2002). Effects of personal control on adoption of self - service technology innovations. Journal of Services Marketing, 16(6), 553-572. doi: $10.1108 / 08876040210443418$

Levin, D., Whitener, E., \& Cross, R. (2006). Perceived trustworthiness of knowledge sources: The moderating impact of relationship length. Journal of Applied Psychology, 91(5), 1163-1171. doi: 10.1037/0021-9010.91.5.1163

Liechty, J., Ramaswamy, V., \& Cohen, S. H. (2001). Choice menus for mass customization: An experimental approach for analyzing customer demand with an application to a webbased information service. Journal of Marketing Research, 38(2), 183-196. doi: 10.1509/jmkr.38.2.183.18849

Little, T. D., Bovaird, J. A., \& Widaman, K. F. (2006). On the merits of orthogonalizing powered and product terms: Implications for modeling interactions among latent variables. Structural Equation Modeling: A Multidisciplinary Journal, 13(4), 497 - 519. doi: $10.1207 / \mathrm{s} 15328007$ sem1304_1

MacKinnon, D. P., Lockwood, C. M., \& Williams, J. (2004). Confidence limits for the indirect effect: distribution of the product and resampling methods. Multivariate Behavioral Research, 39(1), 99-128. doi: 10.1207/s15327906mbr3901_4

Marsh, H. W., \& Hocevar, D. (1985). Application of confirmatory factor analysis to the study of self-concept: First- and higher-order factor models and their invariance across groups. Psychological Bulletin, 97, 562-582. doi: 10.1037/0033-2909.97.3.562 
Matzler, K., Pichler, E., Füller, J., \& Mooradian, T. A. (2011). Personality, person-brand fit, and brand community: An investigation of individuals, brands, and brand communities. Journal of Marketing Management, 27(9-10), 874-890, doi: $10.1080 / 0267257 X .2010 .543634$

McPherson, M., Smith-Lovin, L., \& Cook, J. M. (2001). Birds of a feather: Homophily in social networks. Annual Review of Sociology, 27, 415-444.

Moreau, C. P. (2011). Inviting the amateurs into the studio: Understanding how consumer engagement in product design creates value. Journal of Product Innovation Management, 28(3), 409-410. doi: 10.1111/j.1540-5885.2011.00813.x

Moreau, C. P., Bonney, L., \& Herd, K. B. (2011). It's the thought (and the effort) that counts: How customizing for others differs from customizing for oneself. Journal of Marketing, 75(5), 120-133. doi: 10.1509/jmkg.75.5.120

Moreau, C. P., \& Herd, K. B. (2010). To each his own? How comparisons with others influence consumers' evaluations of their self designed products. Journal of Consumer Research, 36(5), 806-819. doi: 10.1086/644612

Morse, S., \& Gergen, K. J. (1970). Social comparison, self-consistency, and the concept of self. Journal of Personality and Social Psychology, 16(1), 148-156. doi:

$10.1037 / \mathrm{h} 0029862$

O'Cass, A., \& Grace, D. (2008). Understanding the role of retail store service in light of selfimage-store image congruence. Psychology \& Marketing, 25(5), 521-537. doi:

$10.1002 / \operatorname{mar} .20223$

Oyserman, D. (2007). Social Identity and self-regulation. In: Kruglanski, AW.; Higgins, ET., editors. Social Psychology: Handbook of Basic Principles. 2. New York: The Guilford Press; p. 432-453. 
Oyserman D. (2009). Identity-based motivation: Implications for action-readiness, procedural-readiness, and consumer behavior. Journal of Consumer Psychology, 19(3), 250-260. doi: 10.1016/j.jcps.2009.05.008

Park, J. K., Han, H., \& Park, J. H. (2013). Psychological antecedents and risk on attitudes toward e-customization. Journal of Business Research, 66(12), 2252-2259. doi: 10.1016/j.jbusres.2013.05.048

Pavlou, P. A. (2003). Consumer acceptance of electronic commerce: Integrating trust and risk with the technology acceptance model. International Journal of Electronic Commerce, 7(3), 101-134. doi: 10.1080/10864415.2003.11044275

Pavlou, P. A., \& Fygenson, M. (2006). Understanding and predicting electronic commerce adoption: An extension of the theory of planned behavior. MIS Quarterly, 30(1), 115-143.

Power, J., Whelan, S., \& Davies, G. (2008). The attractiveness and connectedness of ruthless brands: the role of trust. European Journal of Marketing, 42(5/6), 586-602. doi: $10.1108 / 03090560810862525$

Randall, T., Terwiesch, C., \& Ulrich, K. T. (2007). Research note: User design of customized products. Marketing Science, 26(2), 268-280. doi: 10.1287/mksc.1050.0116

Reinders, M. J., Dabholkar, P. A., \& Frambach, R. T. (2008). Consequences of forcing consumers to use technology-based self-service. Journal of Service Research, 11(2), 107123. doi: $10.1177 / 1094670508324297$

Rindskopf, D., \& Rose, T. (1988). Some theory and applications of confirmatory secondorder factor analysis. Multivariate Behavioral Research, 23(1), 51-67. doi: 10.1207/s15327906mbr2301_3

Salvador, F., de Holan, P. M., \& Piller, F. T. (2009). Cracking the code of mass customization. Sloan Management Review, 50(3), 71-78. 
Sen, S., \& Bhattacharya, C. B. (2001). Does doing good always lead to doing better? consumer reactions to corporate social responsibility. Journal of Marketing Research, 38(2), 225-243. doi: 10.1509/jmkr.38.2.225.18838

Shavitt, S., Torelli, C. J., \& Wong, J. (2009). Identity-based motivation: Constraints and opportunities in consumer research. Journal of Consumer Psychology, 19(3), 261-266. doi: 10.1016/j.jcps.2009.05.009

Sichtmann, C. (2007). An analysis of antecedents and consequences of trust in a corporate brand. European Journal of Marketing, 41(9/10), 999-1015. doi: $10.1108 / 03090560710773318$

Sirdeshmukh, D., Singh, J., \& Sabol, B. (2002). Consumer trust, value, and loyalty in relational exchanges. Journal of Marketing, 66(1), 15-37. doi:10.1509/jmkg.66.1.15.18449

Sirgy, M. J., Grewal, D., Mangleburg, T. F., Park, J-O., Chon, K-S., Claiborne, C. B., Johar, J. S., \& Berkman, H. (1997). Assessing the predictive validity of two methods of measuring self-image congruence. Journal of the Academy of Marketing Science, 25(3), 229-241. doi: $10.1177 / 0092070397253004$

Skitka, L. J. (2003). Of different minds: An accessible identity model of justice reasoning. Personality and Social Psychology Review, 7(4), 286-297. doi: 10.1207/S15327957PSPR0704_02

Slywotzky, A. (2000). The age of the choiceboard. Harvard Business Review, 78, 40-41.

Steele, C. M., Spencer, S., \& Lynch, M. (1993). Self-image resilience and dissonance: The role of affirmational resources. Journal of Personality and Social Psychology, 64(6), 885896. doi: $10.1037 / 0022-3514.64 .6 .885$

Swann, W. B., Griffin, J. J., Predmore, S. C., \& Gaines, B. (1987). The cognitive-affective crossfire: When self-consistency confronts self-enhancement. Journal of Personality and Social Psychology, 52(5), 881-889. doi: 10.1037/0022-3514.52.5.881 
Swann, W. B., Pelham, B. W., \& Krull, D. S. (1989). Agreeable fancy or disagreeable truth? Reconciling self-enhancement and self-verification. Journal of Personality and Social Psychology, 57(5), 782-791. doi: 10.1037/0022-3514.57.5.782

Syam, N., Krishnamurthy, P., \& Hess, J. D. (2008). That's what I thought I wanted? Miswanting and regret for a standard good in a mass-customized world. Marketing Science, 27(3), 379-397. doi: 10.1287/mksc.1070.0302

Thompson, C. J., \& Haytko, D. L. (1997). Speaking of fashion: Consumers' uses of fashion discourses and the appropriation of countervailing cultural meanings. Journal of Consumer Research, 24(1), 15-42. doi: 10.1086/209491

Thomson, M., Maclnnis, D. J., \& Park, W. (2005). The ties that bind: Measuring the strength of consumers' emotional attachments to brands. Journal of Consumer Psychology, 15(1), 77-91. doi: 10.1207/s15327663jcp1501_10

Tian, K. T., Bearden, W. O., \& Hunter, G. L. (2001). Consumers' need for uniqueness: Scale development and validation. Journal of Consumer Research, 28(1), 50-66. doi: $10.1086 / 321947$

Tian, K. T., \& McKenzie, K. (2001). The Long-Term Predictive Validity of the Consumers' Need for Uniqueness Scale. Journal of Consumer Psychology, 10(3), 171-193. doi:10.1207/s15327663jcp1003_5

Valenzuela, A., Dhar, R., \& Zettelmeyer, F. (2009). Contingent response to selfcustomization procedures: Implications for decision satisfaction and choice. Journal of Marketing Research, 46(6), 754-763. doi: 10.1509/jmkr.46.6.754

van Beuningen, J., de Ruyter, K., Wetzels, M., \& Streukens, S. (2009). Customer selfefficacy in technology-based self-service: Assessing between-and within-person differences. Journal of Service Research, 11(4), 407-428. doi: $10.1177 / 1094670509333237$ 
van der Heijden, H. (2004). User acceptance of hedonic information systems. MIS Quarterly, $28(4), 695-704$.

Venkatesh, V., \& Bala, H. (2008). Technology acceptance model 3 and a research agenda on interventions. Decision Sciences, 39(2), 273-315. doi: 10.1111/j.1540-5915.2008.00192.x

Walsh, G., \& Mitchell, V-W. (2010). The effect of consumer confusion proneness on word of mouth, trust, and customer satisfaction. European Journal of Marketing, 44(6), 838-859. doi: $10.1108 / 03090561011032739$

Wilcox, K., \& Song, S. (2011). Discrepant fluency in self-customization. Journal of Marketing Research, 48(4), 729-740. doi: 10.1509/jmkr.48.4.729

Yim, C. K., Chan, K. W., \& Hung, K. (2007). Multiple reference effects in service evaluations: Roles of alternative attractiveness and self-image congruity. Journal of Retailing, 83(1), 147-157. doi: 10.1016/j.jretai.2006.10.011

Zhang, J., \& Bloemer, J. M. M. (2008). The impact of value congruence on consumer-service brand relationships. Journal of Service Research, 11(2), 161-178. doi:

$10.1177 / 1094670508322561$

Zipkin, P. (2001). The limits of mass customization. Sloan Management Review, 42(3), 81-88. 
Table 1: Conceptualisations of brand identity

\begin{tabular}{|c|c|c|}
\hline Authors & Year & Definition \\
\hline$\overline{\text { Kapferer, J-N. }}$ & 1992 & $\begin{array}{l}\text { The common element sending a single message amid } \\
\text { the wide variety of its products, actions and slogans }\end{array}$ \\
\hline Aaker, D. & 1996 & $\begin{array}{l}\text { Brand identity is a unique set of brand associations } \\
\text { that the brand strategist aspires to create or maintain. } \\
\text { These associates represent what the brand stands for } \\
\text { and imply a promise to customers from the } \\
\text { organization members. }\end{array}$ \\
\hline de Chernatony, L. & 1999 & $\begin{array}{l}\text { Brand identity is reflected by brand's vision and } \\
\text { culture, which drive its desired positioning, } \\
\text { personality, and the subsequent relationships, all of } \\
\text { which are then presented to reflect stakeholders' } \\
\text { actual and aspirational self-images. }\end{array}$ \\
\hline $\begin{array}{l}\text { Aaker, D. A. \& } \\
\text { Joachimsthaler, E. }\end{array}$ & 2000 & $\begin{array}{l}\text { Brand identity represents what the organization wants } \\
\text { the brand to stand for. It needs to resonate with } \\
\text { customers, differentiate the brand from competitors, } \\
\text { and represent what the organization can and will do } \\
\text { over time. }\end{array}$ \\
\hline $\begin{array}{l}\text { Bhattacharya, C.B. } \\
\& \text { Sen, S. }\end{array}$ & 2003 & $\begin{array}{l}\text { Brand identity is the distinctive and relatively } \\
\text { enduring characteristics of a focal brand. A brand } \\
\text { tends to have a strong and attractive identity when the } \\
\text { identity is more distinctive and more prestigious. }\end{array}$ \\
\hline $\begin{array}{l}\text { Brown, T.J., } \\
\text { Kozinets, R. V., \& } \\
\text { Sherry, Jr J.F. }\end{array}$ & 2003 & $\begin{array}{l}\text { Brand identity is the brand's core values, authenticity, } \\
\text { and uniqueness. It is reanimated jointly by } \\
\text { stakeholders and a milieu where marketing } \\
\text { management and consumer commitment coexist. }\end{array}$ \\
\hline de Chernatony, L. & 2006 & $\begin{array}{l}\text { Brand identity is the distinctive or central idea of a } \\
\text { brand and how the brand communicates this idea to its } \\
\text { stakeholders. }\end{array}$ \\
\hline $\begin{array}{l}\text { Da Silveira, C., } \\
\text { Lages, C., \& } \\
\text { Simoes, C. }\end{array}$ & 2013 & $\begin{array}{l}\text { Brand identity is a dynamic concept that originates } \\
\text { among brand managers, and that further develops } \\
\text { through mutually influencing inputs from managers } \\
\text { and other social constituents (e.g., consumers); this } \\
\text { development involves distinguishing, central, and } \\
\text { enduring attributes, where enduring takes a dynamic } \\
\text { meaning-core values maintain consistency over time } \\
\text { while other dimensions vary, when needed, to adjust } \\
\text { to the environmental context. }\end{array}$ \\
\hline
\end{tabular}


Table 2: Sample profile

\begin{tabular}{|c|c|c|c|c|c|}
\hline Age & 15 and under & $16-25$ & $26-35$ & $36-45$ & 46 and over \\
\hline & 29 & 69 & 61 & 28 & 12 \\
\hline \multirow[t]{2}{*}{ Gender } & Female & Male & & & \\
\hline & 86 & 113 & & & \\
\hline \multirow[t]{2}{*}{ Education } & A-level & $\begin{array}{c}\text { Bachelor and } \\
\text { equivalent }\end{array}$ & $\begin{array}{c}\text { Masters and } \\
\text { above }\end{array}$ & & \\
\hline & 51 & 103 & 45 & & \\
\hline \multirow[t]{2}{*}{ Annual Income } & $£ 0-19,999$ & $\begin{array}{c}£ 20,000- \\
39,999\end{array}$ & $\begin{array}{c}£ 40,000- \\
59,999\end{array}$ & $£ 60,000+$ & Unknown \\
\hline & 21 & 61 & 55 & 16 & 46 \\
\hline \multirow[t]{2}{*}{ Experience* } & Yes & No & & & \\
\hline & 62 & 137 & & & \\
\hline
\end{tabular}

Note: Experience means "Experience of using OSC service at least once" 
Table 3: Descriptive statistics, correlations, and scale properties

\begin{tabular}{llllll}
\hline & 1 & 2 & 3 & 4 & 5 \\
\hline 1. Perceived Usefulness of OSC & .79 & & & & \\
2. Trust in OSC & $.21^{* *}$ & .83 & & & \\
3. Need for Uniqueness & $.18^{* *}$ & .11 & .74 & & \\
4. Brand Identity Similarity & $.17^{*}$ & $.37^{* *}$ & .12 & .91 & \\
5. Brand Identity Prestige & .13 & $.41^{* *}$ & -.01 & $.32^{* *}$ & .79 \\
& & & & & \\
Mean & 3.62 & 3.76 & 3.23 & 2.81 & 3.71 \\
Standard Deviation & .83 & .68 & .64 & .98 & .75 \\
Cronbach's $\alpha$ & .82 & .85 & .88 & .87 & .79 \\
AVE & .62 & .69 & .55 & .83 & .63 \\
\hline
\end{tabular}

Note:

AVE $=$ Average Variance Extracted; Scores in the diagonal represent the square roots of AVE scores. ${ }^{*} p<.01 ; * * p<.001 ;$ two-tail test. 
Table 4: Structural Equation Modelling (SEM) results

\begin{tabular}{|c|c|c|c|c|}
\hline & \multicolumn{2}{|c|}{ Main effect model } & \multicolumn{2}{|c|}{ Interaction Model } \\
\hline & Coefficient & C.R. & Coefficient & C.R. \\
\hline BI Prestige $\rightarrow$ Trust & $.67 * * *$ & 7.06 & $.66^{* * *}$ & 7.14 \\
\hline BI Similarity $\rightarrow$ Trust & $.15^{*}$ & 2.13 & $.18^{* *}$ & 2.66 \\
\hline Trust $\rightarrow$ PU & $.22 * *$ & 2.72 & $.16^{\dagger}$ & 1.73 \\
\hline $\mathrm{NFU} \rightarrow \mathrm{PU}$ & $.20^{*}$ & 2.12 & $.19^{*}$ & 2.10 \\
\hline BI Similarity $\rightarrow$ PU & & & .11 & 1.38 \\
\hline $\mathrm{BI}$ Similarity $\times \mathrm{NFU} \rightarrow \mathrm{PU}$ & & & $-.17^{*}$ & -1.99 \\
\hline \multicolumn{5}{|l|}{$\mathbf{R}^{2}$} \\
\hline Trust & & .56 & & .56 \\
\hline PU & & .10 & & .13 \\
\hline
\end{tabular}


Figure 1: Conceptual model and hypotheses

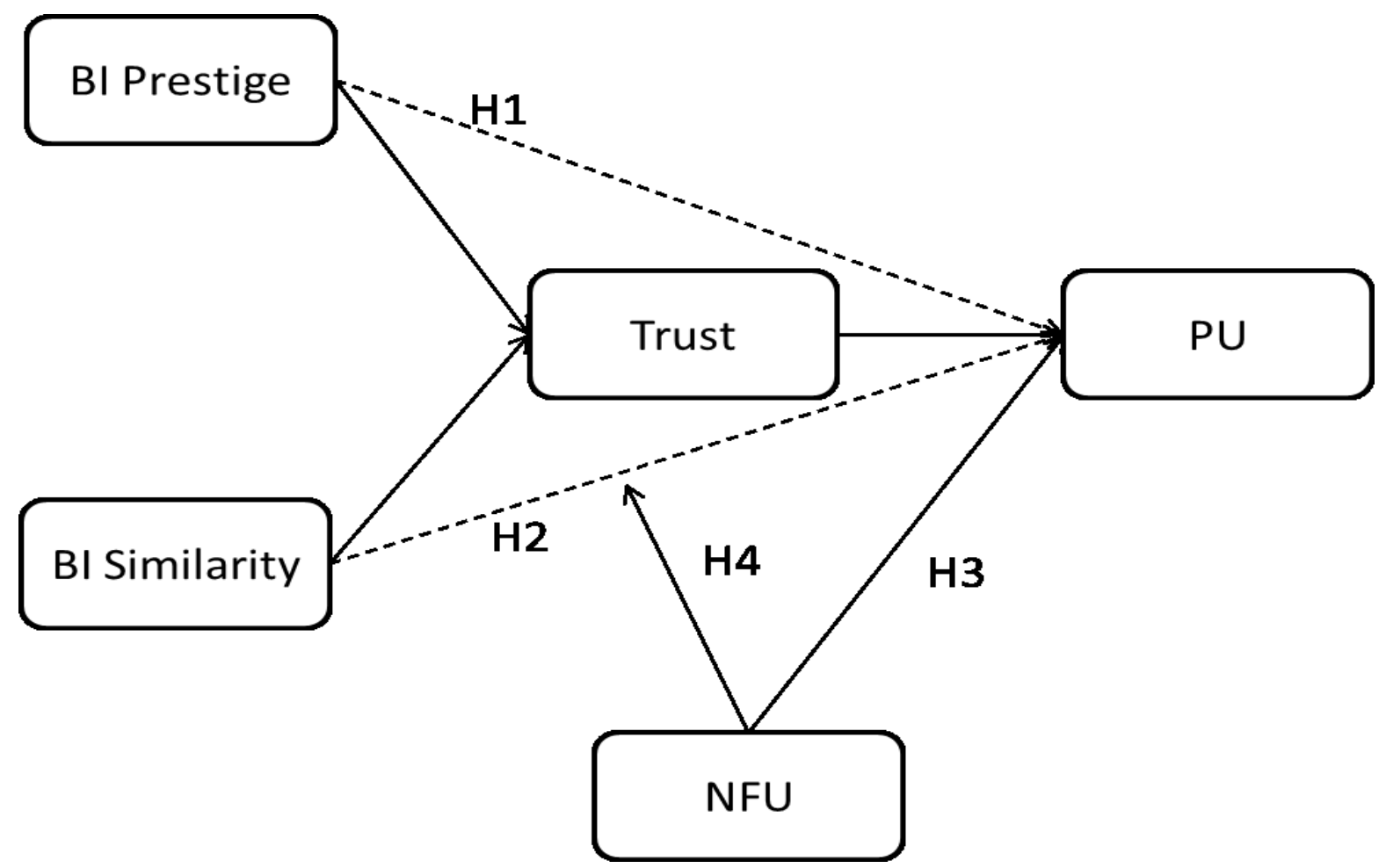

Note: $\mathrm{BI}=$ Brand identity; $\mathrm{PU}=$ Perceived usefulness of OSC $; \mathrm{NFU}=$ Need for uniqueness; Trust $=$ Trust in the focal brand's online self-customisation service.

$\longrightarrow$ : direct effect

$-----\rightarrow$ : indirect effect 
Figure 2: Moderating effect of need for uniqueness on relationship between brand identity similarity and perceived usefulness of OSC

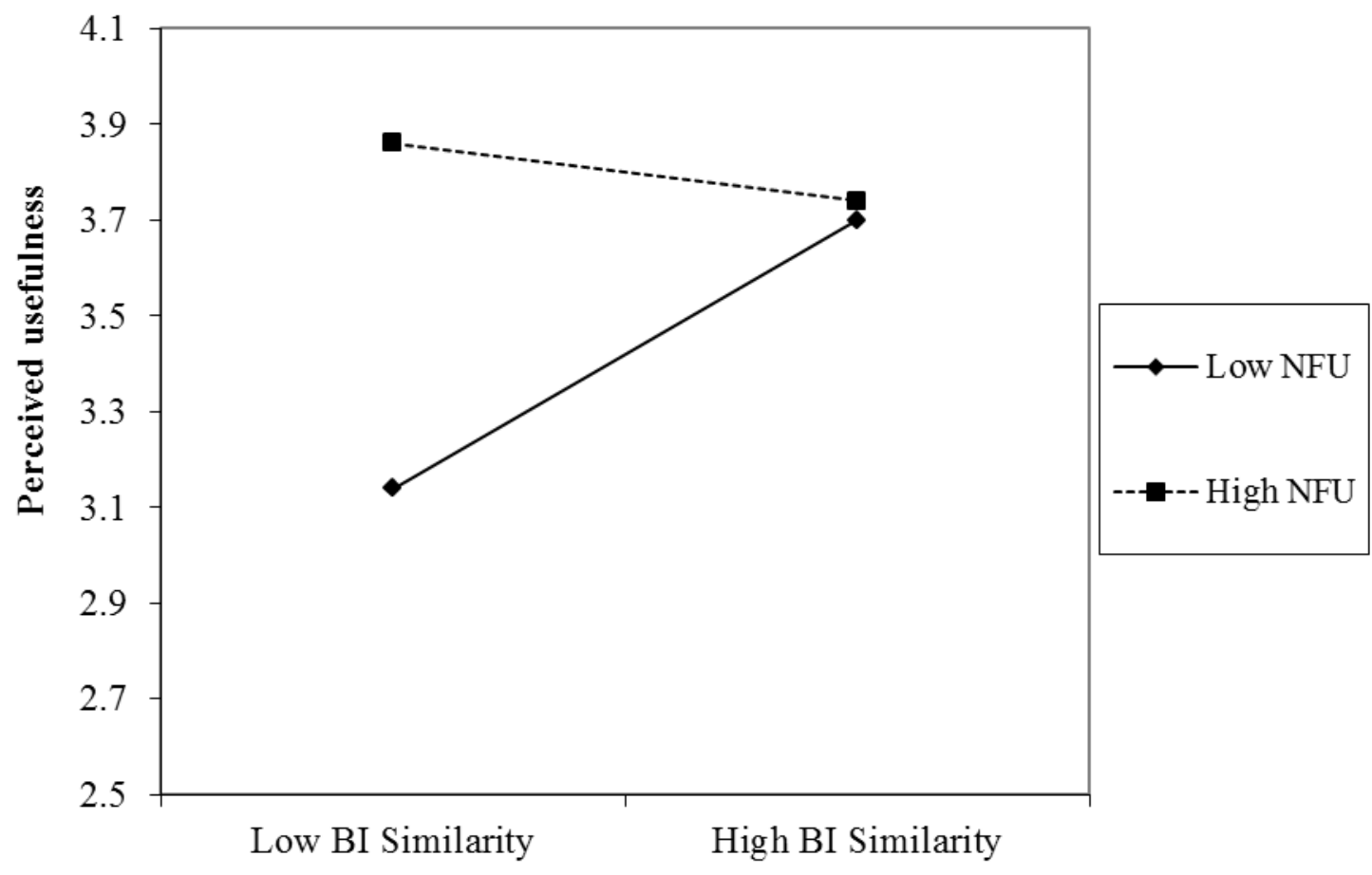

